\title{
Cartilage-hair hypoplasia
}

INSERM

\section{Source}

INSERM. (1999). Orphanet: an online rare disease and orphan drug data base. Cartilagehair hypoplasia. ORPHA:175

Cartilage-hair hypoplasia is a disease affecting the bone metaphyses causing small stature from birth. 